Finanse, Rynki Finansowe, Ubezpieczenia nr 4/2018 (94), cz. 1

DOI: $10.18276 /$ frfu.2018.94/1-04

s. $51-60$

\title{
Depreciation in the Polish income tax system
}

\author{
Jolanta Iwin-Garzyńska*
}

\begin{abstract}
Purpose - The paper discusses the depreciation tax system and summarizes the provisions of Polish law on corporate income tax.

Design/methodology/approach - Methods of literature analysis and critical analysis of tax law, corporate income tax.

Findings - The paper present the essence of tax depreciation in the Polish income tax system.

Originality/value - Original presentation of the tax aspect of depreciation in the context of the corporate finance.
\end{abstract}

Keywords: finance, corporate finance, corporate income tax, depreciation tax system

\section{Introduction}

The provisions of the Corporate Income Tax Act (hereinafter referred to as: the Act) provide for a special way to take into account tax deductible expenditures on goods that wear and tear over a longer period, i.e. fixed assets and intangible assets. The essence of these regulations is that expenses for their acquisition are not included in the tax deductible costs directly, but indirectly, through depreciation expenses made by a company.

The purpose of the article is to discuss the importance of the tax system of depreciation in the corporate finance with the consideration of the Polish law, i.e. the Corporate Income Tax Act. Main hypothesis publications: preferential tax depreciation may be important for a corporate.

\section{Depreciation in the Polish tax system}

The concept of tangible assets is defined in article 16a paragraph 1 of the Act, which provides that, subject to article 16c, depreciation shall include owned or jointly owned by the taxpayer, purchased or produced, complete and fit for use on admission to use structures, buildings and premises; machinery, equipment and transportation means, and other items with an estimated life longer than one year, used by the taxpayer for the purpose of business activities or put into use on the basis of rental, lease or other agreement of similar nature.

* prof. dr hab. Jolanta Iwin-Garzyńska, Department of Corporate Finance and Taxation, Faculty of Economics and Management, University of Szczecin, Szczecin Poland, e-mail: jiwin@wneiz.pl. 
Fixed assets were also mentioned in paragraph 2 of the same article. The provision provides an exhaustive list of grounds that must be met to include the items referred to in paragraph 1 of this provision into fixed assets which are subject to tax depreciation ${ }^{1}$.

In determining the deductible under the provisions of the income tax, exceptional position is granted to costs not considered by legislator as deductibles (Act, 1992, art. 16 par. 1). The Corporate Income Tax Act determines that deductible expenses do not include expenses, e.g., paid for:

- acquisition of land or the right of perpetual usufruct of land, with the exception of fees for perpetual use of land;

- purchase or production of tangible fixed assets and intangible assets, including those belonging to the acquired company or its organized parts;

- improvements of fixed assets which increase the value of these assets that forms the basis for calculating depreciation - however, these expenditure after updating, minus net amortization charges, are deductible in determining the income from the sale of property and property rights, regardless of the time they are incurred.

Deductible depreciation expenses are made in accordance with the principles derived from article $16 \mathrm{a}-16 \mathrm{~m}$ of the Corporate Income Tax Act. It should also be noted that deductible costs shall not include depreciation expenses made of fixed assets (intangible assets) acquired in the form of an in-kind contribution from that part of their value which was not communicated to the creation or increase of the share capital of a capital company. They are particularly interesting because they stipulate that expenditure on the acquisition or construction of the asset are not deductible from income because these costs can be recognized only gradually through depreciation charges (Act, 1992, art. 16 par. 1 item 63d).

Increasing deductible costs with depreciation are not the only way to take account of the expenditure on the acquisition of fixed assets and intangible assets in deductibles. These expenditures will increase expenses upon paid disposal (less the sum of charge-offs and amortization). In this way, they will also include expenditure on acquisition of fixed assets not subject to depreciation (e.g. land) (Kubacki, 2012, p. 248).

For expenditure to be recognized as tax deductible cost, there should be causal link between revenue and the cost of their acquisition. With regard to fixed assets, the causal relationship alone is not sufficient for the costs incurred by the company on their use to be recognized as deductibles by the income tax system. The company makes investments in fixed assets for the purpose of obtaining income, then it operates to give a specific revenue. The causal link between the revenue and the costs of obtaining it is very clear. With regard to fixed assets, deductibles incurred by the company must, however, be sanctioned by law, because otherwise they cannot be classified as those costs. Failure to include certain costs associated with the operation of the asset in deductibles (i.e. limiting the size of depreciation) affects the scope of the depreciation tax shield.

Tax depreciation is determined by a depreciation system featuring fiscal stringency which means that it has been created primarily for tax purposes. The cost of the asset incurred in

\footnotetext{
1 See: e.g. Ruling of the Supreme Administrative Court of 21.06.2006.
} 
the form of depreciation during its use should be sanctioned by the norms of financial law shaping the system. Tax costs of depreciation must also satisfy the condition concerning the causal link between the cost of depreciation of the fixed asset and the proceeds from its operations. This was confirmed by the Supreme Administrative Court which pointed out that the structure taking into account the cost in the form of depreciation of an asset corresponds to the general rule under which there must be a causal link between the cost in the form of depreciation of an asset and the revenue obtained from the use of that asset in business ${ }^{2}$.

While assessing the solutions of the financial system in terms of the relationship between deductible costs under tax law norms and the value of depreciation tax shield, one shall not forget about possible use of different depreciation methods as instruments for stimulating the amount of deductible costs. In the literature we can distinguish various methods of depreciation of fixed assets and intangible assets.

In the Act on Corporate Income Tax in the part concerning depreciation, the legislator provided for the possibility of the use by the company of three methods of depreciation included in deductibles. These methods are as follows: one-time, linear and degressive (Głuchowski, Handor, Patyk, Szymańska, 2002, p. 193). The company makes depreciation and amortization of depreciable assets from the initial value starting from the first month following the month in which the asset was entered into the records. The company itself selects one of the methods of amortization before starting depreciation and applies selected method to fully accommodate a given asset ${ }^{3}$. Any adjustment to depreciation is possible only in exceptional cases, e.g. when the company incorrectly determined the amount of depreciation, incorrectly identified the initial value of property, has used wrong rate, but only when using the linear method and the rates set forth in the annex to the act ${ }^{4}$. During the depreciation of an asset, the depreciation method regarding such asset cannot be changed ${ }^{5}$. The Corporate Income Tax Act does not define the term "amortization method". The Accounting Act also does not contain such a definition. However, the provisions of the Act on Income Tax state that entrepreneurs have a choice between three depreciation methods:

- linear depreciation using standard, elevated or reduced depreciation rates specified on the list annexed to the Act (1992, art. 16i par. 1, 2 and 5),

- linear depreciation using individual depreciation rates (Act, 1992, art. 16j par. 1),

- degressive depreciation (Act, 1992, art. 16k).

In accordance with the provisions of the Act, one-time method does not apply as a way of making depreciation. This may be due to the fact that using one-time write-off in the company causes that there will be no regular depreciation. However, for the purpose of analysing the possibility of a depreciation tax shield one-time charge is important.

\footnotetext{
2 See: Ruling of the Supreme Administrative Court of 27 March 2003.

3 According to the provisions of the Act on Corporate Income Tax, taxpayers have to apply their method of choice until the asset has been fully depreciated. See: Act (1992), art. 16h par. 2.

4 See: Ruling of the Supreme Administrative Court of 17 April 2008.

5 See: Ruling of the Supreme Administrative Court of 6 June 2006.
} 
The one-time method relies on a single completion of deductible costs of the acquired asset. The Act provides that taxpayers may not make depreciation and amortization of assets whose initial value do not exceed PLN 3,500 (from 2018 - PLN 10,000), and expenses for their purchase are a tax deductible in a month of their use. It is the right of a company, not an obligation. This provision is optional. It should be added that taxpayers are required to enter such an asset to the records maintained in accordance with the provisions of the Accounting Act (1994, art. 17 par. 1 item 1), no later than in a month of their entry into use.

The possibility of a single inclusion of the value of fixed asset in deductible costs is related to the provision of the Act which provides for such possibility for fixed assets with an initial value in excess of PLN 3,500, if due to the period of expected use equal to or less than a year it will not be included into the company fixed assets.

In accordance with the provisions of the Act, if the taxpayers purchase or produce inhouse assets with initial value in excess of PLN 3,500 (from 2018 - PLN 10,000), and due to their expected period of use being equal to or less than a year they do not recognize them as fixed assets, and the actual period of their use exceeds a year, the taxpayers are obliged, in the first month following the month in which the year has passed:

- to include these components into fixed assets or intangible assets at the purchase price or cost of production,

- to reduce the tax deductible expenses by a difference between a purchase price or production cost and the amount of depreciation attributable to the period of their current use, calculated for fixed assets using the depreciation rates set out in a schedule on annual depreciation rates constituting Annex 1 to the Act,

- to apply the depreciation rates referred to in paragraph 2 , throughout the period of depreciation,

- to deposit, before the 20th day of the month, to the tax office the amount of interest accrued from the date of crediting deductible costs of expenditure for the acquisition or construction of their own assets until the date on which the period of their use reached one year, and the accrued amount of interest shown in statement referred to in article 27, paragraph 1; interest on a difference referred to in paragraph 2 shall accrue at the rate of interest for late payment of tax arrears in force on credit asset to fixed assets (see: Act, 1992, art. 16e).

The linear method is based on making write-offs in equal monthly or quarterly instalments or once at the end of the fiscal year; this is the basic method of amortization. This method consists in the fact that depreciation takes place from the first month following the month in which the asset was entered into the records. In relation to this method, the legislator has provided for the possibility of use by entrepreneurs of increased and individual rates of depreciation.

The possibility of increasing depreciation rates may be applied to buildings and structures used in degraded or bad conditions, assets subject to rapid technological advances, used more intensively in relation to average conditions or requiring special technical efficiency.

In accordance with the provisions of the Act, taxpayers may increase the rates subject to the list of depreciation rates: 
1) for buildings and structures used in the following conditions:

a) degraded - using coefficients not higher than 1.2,

b) bad - using coefficients not higher than 1.4 ,

2) for machines, equipment and means of transport, except sea stock, used more intensively in relation to average conditions or requiring special technical efficiency when used in this period, using coefficients not higher than 1.4,

3) for plant and equipment included in groups: 4-6 and 8 in the Fixed Assets Classification issued on the basis of separate provisions and subject to rapid technological advances, using coefficients not higher than 2.0.

In the event of termination or conditions that justify an increase in the rates referred to in paragraph 2 points 1 and 2 of the Corporate Income Tax Act, these rates are increased or decreased from the month following the month in which the circumstances justifying these changes occurred.

A company is also able to reduce the depreciation rate specified in the Annex to the $\mathrm{Act}^{6}$. Such a possibility is not dependent on the occurrence of any circumstances. This underlines the fiscal nature of provisions concerning the principles of depreciation of fixed assets. By lowering the rate, the company can be guided by the principle of adequacy of depreciation cost for the productivity of the asset. As a result of rate reduction, the income tax base is increased, tax payments increase, the tax shield is reduced, and consequently the value of capital is adversely affected.

Lowering depreciation rates is made from the month in which the assets were introduced into the records or from the first month of each subsequent fiscal year. The Act does not ban the reduction in the rate of depreciation of the fixed asset even several times. The taxpayer may then change the rates, i.e. reduce or increase the previously reduced rate, starting from the first month of each next fiscal year. In this situation, it has the possibility of applying different depreciation rates for fixed assets for each fiscal year, with the only proviso that the rates were not higher than the rates specified in the Schedule of depreciation rates (see: Interpretation, 2013).

On the one hand, the possibility of increasing and decreasing depreciation rates reflects the spirit of flexibility of tax solutions. This principle is one of the fundamental rules in designing a common consolidated tax base, the concept of income tax harmonization in the European Union. On the other hand, the concept seeks solutions favoring standardization and objectification of determining the taxable income, and thus easier comparisons of tax burdens (Supera-Markowska, 2010, p. 205).

The present system of depreciation of assets provides companies with the possibility of using individual depreciation rates for improved or used fixed assets. The rates for these assets are determined by the company itself, although the depreciation period resulting from the rate applied cannot be less than the one specified in the Act for individual groups of assets (Litwińczuk, 1996, p. 184). However, as for the possibility of increasing depreciation rates, the possibility to use individual rates is very limited. These limits are designed to prevent fraud on the part of companies, but also the circle of those who may benefit from the preferential possibility of depreciation of fixed assets has been narrowed down.

6 According to article 16i paragraph 5 of the Act, taxpayers can reduce the depreciation rates specified in the Schedule for individual fixed assets. 
Increased depreciation rates within the limits set by the tax law are calculated using the linear method of depreciation. In addition to this method, Polish tax law allows for the use of degressive depreciation, i.e. accelerated depreciation. It is considered a form of tax preference, as increased write-offs result in decreasing the taxable income of the company and consequently the income tax.

Accelerated depreciation is used in many countries, including the United States, Germany and Japan (Tax Guide for Small Business 1993, pp. 55-59). The modified MACRS system for the recovery of costs that was introduced in the United States is of particular interest. The two methods of depreciation it uses are based on the degressive method. Japan, on the other hand, applies an accelerated method of depreciation for computers, numerically controlled machine tools, some branches of electronics, nuclear energy, etc. (Ozaki, 1988, pp. 86-92). The European Union tax directives also state that the taxpayer should have the choice between accelerated depreciation on a degressive basis and linear depreciation. Also in the works on the CCCTB concept, leaving the entrepreneurs the opportunity to choose between linear and the degressive depreciation method would allow them to adjust to the asset the method that best reflects its consumption?

Accelerated depreciation (see: Act, 1992, art. 16k) of a degressive nature may be used for machinery and equipment classified in accordance with the classification of types of CSO fixed assets groups 3-6 and 8 and means of transport, with the exception of passenger cars. In accordance with the provisions of the Act, in the first year of using a fixed asset the company uses depreciation rates included in the list increased by a factor not higher than 2 , and in subsequent fiscal years it makes tax write-downs from the initial value decreased by amortization write-downs accumulated so far, established at the beginning of consecutive years of use. It follows that the basis for depreciation is the net value of the asset. Starting with tax year in which the annual depreciation amount determined in this way would be lower than the annual amount of depreciation calculated using the linear method, the company makes further write-offs using the linear method. The coefficient of increase in the depreciation rate when using the degressive method may not exceed 3, but only if you use assets that can be depreciated using this method, in a facility located in the municipality of specific risk or high structural unemployment, or in the municipality at risk of recession and social degradation ${ }^{8}$.

The regulations on the degressive method also contain provisions favorable to entrepreneurs who have started a business as well as for "small taxpayers". These entrepreneurs can

7 See: An Overview of the Main Issues that Emerged at the First Meeting of the Subgroup on tax Depreciation of Assets, CCCTB/WP/007/doc.en, Brussels, 23.02.2005, p. 3; Summary Record of the Meeting of the Common Consolidated Corporate Tax Base Working Group, CCCTB/WP/013, Brussels, 8.07.2005, p. 5.

8 A list of these municipalities is determined by the Council of Ministers. Currently there is no list of municipalities at risk of high structural unemployment or municipalities threatened by recession and social degradation. This provision is not in practical use.

9 In accordance with the provisions of the Act, a "small taxpayer" is one whose value of sales revenues (together with the amount of value added tax) did not exceed the equivalent of EUR 1,200,000 in the previous fiscal year, expressed in the Polish currency (zloty). The amount is converted into zlotys at the average euro exchange rate published by the NBP on the first working day of October of the year preceding the fiscal year, rounded to PLN 1,000. In 2018, a small taxpayer can be considered an individual whose proceeds from sale, together with VAT for 2017 did not exceed PLN 5,176,000. 
take advantage of a one-off depreciation including amortization write-off up to $100 \%$ of the initial value of the asset in the first tax year (article 16k of the Act). This applies to fixed assets of groups 3-8 in the fixed assets classification, including machinery, equipment and means of transport, with the exception of passenger cars. The total amount of write-offs made using this method of depreciation of fixed assets entered into the register in the given year may not exceed the equivalent of 50,000 euros ${ }^{10}$. The preferential method of depreciation write-offs provides for the minimal aid to the extent and under the terms of the acts of EU law ${ }^{11}$.

Amortisation also covers acquired property rights such as licenses, copyrights, industrial property rights and know-how, as well as goodwill, development costs, or intangible assets. With the amortisation of these values the principle shall be applied that the depreciation period may not be less than the statutorily specified number of months, e.g. for a license (sub-license) for computer software and copyrights -24 months.

\section{Depreciation tax system in empirical research}

In the reports of the Ministry of Finance, only preferential rules for entrepreneurs who have started a business and for "small taxpayers" have been recognized as tax preferences ${ }^{12}$. One may assume that taking into account only the "depreciation allowances" the Ministry does not see the issue of financial burden of other depreciation solutions.

The aim of this study was to analyse the depreciation system. By reference to the depreciation method, it may be emphasized that Polish companies have the opportunity to shape depreciation, reducing the size of the tax outflows, and ultimately influence the size of the income taxes paid. It is, therefore, important that Polish companies use the possibility "given" to them by the legislature. Exploring the propensity to use depreciation allowances as a part of deductible expenses is important from the possibility of harmonizing tax depreciation system within the European Union. The first study in terms of the propensity of Polish enterprises was carried out in $2002^{13}$. The corresponding data are shown in Table 1.

10 In 2018, the limit of one-off depreciation in accordance with the above Act was PLN 216,000.

11 The de minimis principle within the Community is indicated in Commission Regulation (EC) No 1998/2006 on the application of article 87 and 88 of the Treaty on de minimis aid. De minimis aid is the aid granted to the same economic entity during the current financial year and the two previous fiscal years, which does not exceed the equivalent of EUR 200,000. See: Official Journal of the European Union L379/5 of 28.12.2006.

12 See: Tax Preferences in Poland (2010). Report of the Ministry of Finance. Annex B: The Value of Tax Preferences, Warsaw, p. 12.

13 The research was conducted within the framework of the research project KBN titled Depreciation tax shield and the value of property investment in companies (No. $2 \mathrm{H} 02 \mathrm{C} \mathrm{09822),} \mathrm{head} \mathrm{of} \mathrm{the} \mathrm{project} \mathrm{-} \mathrm{J.} \mathrm{Iwin-}$ -Garzyńska. The study group consisted of about 250 companies, dominated by limited liability companies and joint-stock companies 
Table 1

The importance of accelerated depreciation methods for companies ( 0 - unimportant, 5 - important) (in \%)

\begin{tabular}{lllllllll}
\hline & 0 & 1 & 2 & 3 & 4 & 5 & Total \\
\hline Degressive & 79 & 2 & 3 & 7 & 3 & 7 & 100 \\
\hline Raising rates & 67 & 0 & 5 & 8 & 13 & 7 & 100 \\
\hline Individual depreciation & 72 & 3 & 3 & 7 & 5 & 10 & 100 \\
\hline No matter - liner depreciation & 25 & 3 & 7 & 3 & 5 & 57 & 100 \\
\hline
\end{tabular}

Source: author's own calculation based on surveys.

Data in Table 1 show that for the majority of the companies surveyed, accelerated depreciation method was not important. As many as $79 \%$ of the surveyed companies showed that the declining balance method is irrelevant for the formation of the size of depreciation as a source of investment financing. The reason for this state of affairs may be the reluctance to increase operating costs, simplicity of setting a linear write-downs and poor perception of amortization of financial assets by the financial and accounting companies (Iwin-Garzyńska, 2005, pp. 154-155).

The second study was also carried out in 2010-2012 under the project funded by the Ministry of Higher Education. The corresponding data are included in Table 2.

\section{Table 2}

The importance of accelerated depreciation methods for companies ( 0 - unimportant, 5 - important) (in \%)

\begin{tabular}{lccccccccc}
\hline & 0 & 1 & 2 & 3 & 4 & 5 & $\begin{array}{l}\text { No } \\
\text { answer }\end{array}$ & Total \\
\hline Degressive & 21.8 & 5.5 & 1.8 & 0 & 0 & 1.8 & 69.1 & 100 \\
\hline Raising rates & 14.3 & 3.6 & 5.4 & 7.1 & 1.8 & 0 & 67.8 & 100 \\
\hline Individual depreciation & 19.6 & 1.8 & 0 & 1.8 & 5.4 & 1.8 & 69.6 & 100 \\
\hline One-off deduction & 8.9 & 3.7 & 0 & 8.9 & 0 & 8.9 & 69.6 & 100 \\
\hline $\begin{array}{l}\text { No matter-liner } \\
\text { depreciation }\end{array}$ & 14.3 & 0 & 3.6 & 3.6 & 0 & 8.9 & 69.6 & 100 \\
\hline
\end{tabular}

Source: author's own calculation based on surveys.

Data in Table 2 show that the tax depreciation methods are immaterial for companies, since a vast group of surveyed companies did not reply to the question, and among those which responded a dominated answer pointed out for the irrelevance of depreciation methods. This can prove two hypotheses. Firstly, Polish companies truly consider provisions for accelerated depreciation methods to be irrelevant. Secondly, in practice, they use the solutions, but to a limited extent or with no knowledge of doing so. The proof to this hypothesis may be the 
low score of one-time deductions. In practice, however, one-time deductions of fixed assets of initial value up to PLN 3,500 (in 2018 up to PLN 10,000) are almost universal.

The opinion of the Polish companies is similar to the standpoint of the Ministry of Finance, for whom the records of the tax depreciation system are irrelevant because the only preference is a one-off depreciation.

\section{Conclusions}

In the system of tax depreciation, both in the Polish law - the Corporate Income Tax Act and the draft directive of the CCCTB, the theory of fiscal illusion is revealed which consists of hidden taxation, the amount of actual tax burdens, diversity of the tax burden. These illusions can be triggered by, among others, making an impression that the taxes paid by the company are preferred because they result in extraordinary benefits (Owsiak, 2005, pp. 228-229 $)^{14}$. The introduction of many tax depreciation methods in the Act promotes the formation of the illusion that the burden for the taxpayer is smaller than in the case of one method. Depreciation provisions are explained in a such way that the company may obtain advantages since as a result of tax savings it has additional capital to fund operations and development. However, this is only an illusion because - as the research shows - companies fail to see the relevance of diversity in tax depreciation methods.

\section{References}

Accounting Act of 29 September 1994. Journal of Laws of 2018, item 395.

Act of 15 February 1992 on Corporate Income Tax. Journal of Laws of 2000, No. 54, item 654, as amended.

Głuchowski, J., Handor, D., Patyk, J., Szymańska, J. (2002). Formy zmniejszania wysokości podatków w Polsce. Warsaw: Polish Scientific Publishers PWN.

Interpretation of the director of the Tax Chamber in Poznań of 26 August 2013. No. ILPB4/423-182/13-2/DS.

Iwin-Garzyńska, J. (2005). Kapitał amortyzacyjny w zarządzaniu finansami. Warsaw: PWE.

Iwin-Garzyńska, J. (2016). Common Consolidated Corporate Tax Base (Ccctb) in the Theory of Corporate Finance. International Journal of Accounting and Taxation, 1 (4), 17-51.

Kubacki, R. (2012). Koszty uzyskania przychodów w podatkach dochodowych. Wrocław: Unimex.

Litwińczuk, H. (1996). Prawo podatkowe podmiotów gospodarczych. Warsaw: KiK.

Owsiak, S. (2005). Public Finances. Theory and Practice. Warsaw: Wydawnictwo Naukowe PWN.

Ozaki, N. (1998). An Outline of Japanese Taxes. Tokyo: Tax Bureau Ministry of Finance.

Ruling of the Supreme Administrative Court of 17 April 2008. II FSK 282/07. Retrieved from: http://orzeczenia. nsa.gov.pl.

Ruling of the Supreme Administrative Court of 21 June 2006. II FSK 921/05. Legalis.

Ruling of the Supreme Administrative Court of 27 March 2003. SA/Bd 482/03 unpublished.

Ruling of the Supreme Administrative Court of 6 June 2006. II FSK 909/05. Published MP 2006/12/44.

14 S. Owsiak presents more activities which produce tax illusion. Here we point out the most important ones from the point of view of the subject study. See: Owsiak (2005), pp. 228-229. 
Supera-Markowska, M. (2010). Wspólna skonsolidowana podstawa opodatkowania jako koncepcja harmonizacji opodatkowania korporacyjnego w UE. Warsaw: C.H. Beck.

Tax Guide for Small Business (1993). Internal Revenue Service. Washington D.C.

\section{AMORTYZACJA W POLSKIM SYSTEMIE PODATKU DOCHODOWEGO}

Streszczenie: $\mathrm{Cel}-\mathrm{W}$ artykule przedstawiono istotę system amortyzacji podatkowej z ukazaniem zapisów ustawy o podatku dochodowym od osób prawnych w tym zakresie.

Metodologia badania - Zastosowano metody analizy literatury oraz krytycznej analizy prawa podatkowego, szczególnie podatku dochodowego od osób prawnych.

Wynik - Zaprezentowano istotę amortyzacji podatkowej w polskim systemie podatku dochodowego.

Oryginalność/wartość - oryginalne zaprezentowanie podatkowego aspektu amortyzacji w kontekście finansów przedsiębiorstwa.

Słowa kluczowe: finanse, finanse przedsiębiorstwa, podatek dochodowy od osób prawnych, system podatkowy amortyzacji

\section{Citation}

Iwin-Garzyńska, J. (2018). Depreciation in the Polish Income Tax System. Finanse, Rynki Finansowe, Ubezpieczenia, 4 (94/1), 51-60. DOI: 10.18276/frfu.2018.94/1-04. 